\title{
Government Debt Reduction in the Old EU Member States: Is This Time Different?*
}

\author{
Miklós Losoncz - Csaba G. Tóth
}

The international financial and economic crisis that started in 2007 and was referred to as the Great Recession, and the subsequent sovereign debt crisis, led to a significant increase in the government debt ratio (the ratio of gross government debt to GDP) in the European Union. This was followed by a gradual and lasting consolidation in the old EU Member States (EU15), which had last been seen from the mid-1990s onwards and which ended precisely because of the economic crisis. In our study, we use a debt decomposition analysis to show the main similarities and differences between the debt reduction period in the second half of the 2010s and the one that ended with the outbreak of the previous Great Recession. In both periods, the government debt ratio declined to a nearly similar extent on an annual average in almost two-thirds of the EU15 group of countries. However, in addition to this similarity, there were significant differences in the structure of consolidation. In the period from the mid-1990s to the 2007-2009 crisis, disciplined fiscal policy, in particular, stimulated debt reduction through the primary balance, the effect of real GDP growth was offset by the impact of real interest rates and the other items did not play a significant role. By contrast, the effect of fiscal policy has been much smaller in the debt reduction experienced over the past nearly half a decade, whereas the lower level of interest rates and the other items have contributed substantially to the consolidation process. The favourable international interest rate environment has made fiscal policy complacent. If monetary policy support is terminated or weakening, the role of fiscal policy in reducing the government debt ratio will become more important again to the EU15 states.

\section{Journal of Economic Literature (JEL) codes: H63, H60, E62, E63}

Keywords: fiscal policy, government debt, EU15, debt reduction, budget balance, consolidation

* The papers in this issue contain the views of the authors which are not necessarily the same as the official views of the Magyar Nemzeti Bank.

Miklós Losoncz (DSC) is Professor at the Faculty of Finance and Accountancy of Budapest Business School. E-mail: losoncz.miklos@uni-bge.hu

Csaba G. Tóth (PhD) is Research Fellow at the Hungarian Demographic Research Institute of the Hungarian Central Statistical Office (HCSO). E-mail: toth@demografia.hu

This study was written with the support from the Office for Research Groups Attached to Universities and Other Institutions, through funding provided to the MTA-BGE Macroeconomic Sustainability Research Group. Prof. Miklós Losoncz is the leader of the research group.

The Hungarian manuscript was received on 16 March 2020.

DOI: http://doi.org/10.33893/FER.19.2.2854 


\section{Introduction ${ }^{1}$}

It is not without reason that the nearly one and a half decades that preceded the international financial and economic crisis ${ }^{2}$ of 2007-2009 entered history books as the period of the Great Moderation (Bernanke 2004). Compared to previous years, the volatility of key macroeconomic indicators decreased significantly and, with a few exceptions, the management of the general government of EU Member States was also relatively calm. Although there were significant differences between individual countries, fiscal consolidations, which began in the 1990s and proved more or less effective in improving short-term imbalances, also led to halting and reversing the increase in gross government debt relative to GDP (Baldacci et al. 2014). However, the international financial and economic crisis, which marked the beginning of a new era in economic history, suddenly ended the carefree years of fiscal policy. This has forced economists and policy makers to reconsider their views on fiscal policy (Muraközy 2012). This was necessary, among other things, because within a few years the financial crisis and subsequent real economic crisis then triggered a sovereign debt crisis in several countries in the EU and the euro area, and even elsewhere. Governments of more than half a dozen states were forced to seek financial help from various international organisations to meet their payment obligations (Tóth 2014, Tóth 2017, Losoncz 2014). The significance of the problem we examine is indicated by the fact that even in its 2019 medium-term forecast (European Commission 2019), the European Commission found a medium or high risk to the sustainability of public finances in almost half of the EU Member States. ${ }^{3}$

It is thus understandable that - following the Great Recession and the ensuing sovereign debt crisis - most European states tried to consolidate their fiscal positions by gradually rectifying their imbalances and reducing their debt ratios. Due to significant differences in fiscal and cyclical positions, the turnaround did not occur simultaneously in all countries, but in 2015 the average debt ratio of the EU15 also started to decline, and since then the indicator has been falling year after year. This trend has been temporarily interrupted by the Covid-19 pandemic that appeared in early 2020 and then became global, or more precisely by the restrictions imposed to curb the pandemic and the adverse impact of government programmes on equilibria aimed at mitigating the economic downturn. Although the uncertainty about the expected, year-end debt ratios is enormous, according to the IMF (2020) forecast published in April, gross domestic product in the euro area may contract by 7.5 per cent in 2020. This suggests that 2019 most likely marked

\footnotetext{
${ }^{1}$ We thank the anonymous peer reviewers for their helpful suggestions.

${ }^{2}$ According to the official position, the recession in the US began in December 2007 and ended in June 2009, i.e. it lasted 18 months. According to the criteria of the International Monetary Fund, there was a global economy-wide recession in 2009.

${ }^{3}$ For more information on fiscal sustainability, see the works of Burnside (2005), Castro - De Cos (2002), Agnello - Souza (2009), Presbitero (2011).
} 
the end of the five-year period of fiscal consolidation and debt ratio reduction in EU15 states. In other words, the period that allowed for the expansion of fiscal leeway thanks to favourable cyclical conditions came to an end, and this leeway significantly determines each country's ability to deal with the pandemic and the associated economic crisis.

These processes can also be well demonstrated on the basis of specific numbers. In the old EU Member States (hereinafter referred to as EU15), the government debt ratio rose from 24 to 70 per cent between 1974 and 1996. Thereafter, the indicator decreased by almost 15 percentage points by the beginning of the crisis in 2007 . As a result of the international financial and economic crisis of 2007-2009 and the ensuing sovereign debt crises, the EU15 government debt ratio rose again to an average of 92 per cent in 2014, before declining anew by almost 10 percentage points between 2015 and 2019. In other words, the debt reduction period that ended last year cannot be considered unprecedented.

However, the almost similar rate of decline in government debt during the two periods may be due to different developments. We examine these in our study, seeking answers to the following questions: To what extent are the two periods similar and different? What were the driving factors behind the debt reduction before the Great Recession? And which factors formed the basis for the consolidation carried out in the second half of the 2010s? Comparing the two periods is useful and instructive, not only to better understand the economic and social contexts behind the fiscal phenomena, but because past experiences can provide answers to our questions about current events as well. There has been a particularly intense debate among economic policy makers and economic professionals ${ }^{4}$ about the pace and effectiveness of recent debt reductions. Past experiences, in turn, can serve as guidance for the future, enriching our knowledge with new information and conclusions.

The nature of the study is an international comparative analysis based on statistical methods (decomposition of debt dynamics). The 15 old Member States of the European Union were included in the comparison. This is because, on the one hand, a sample of 15 countries is still relatively easy to handle. On the other hand, compliance with the public debt convergence criteria set out in the Maastricht Treaty (gross government debt not to exceed 60 per cent of GDP) and fulfilment of the enhanced provisions of the Stability and Growth Pact exerted significant external pressure on the economic policy and, within that, the fiscal policy of the Member States surveyed, particularly in the Economic and Monetary Union. Finally, the countries of Central, Eastern and Southern Europe, which joined the EU in 2004, 2007 and 2013, were excluded from the comparative analysis because in the

\footnotetext{
${ }^{4}$ See the works of La Torre - Marsiglio (2019) and Bouabdallah et al. (2017).
} 
1990s most of them were struggling with the consequences of the transition to the market economy. This also left its mark on their fiscal policies and government debt positions. The scientific novelty of the paper lies in the fact that the recent debt reduction period was not analysed in isolation, as the characteristics and relationships behind the consolidation are analysed in comparison to an earlier period without major disturbances.

After the introduction, we review the possible types of debt reductions and then summarise how the government debt ratio developed in the EU15 group of countries in the analysed periods. Next, we present the stages and parameters of the debt decomposition analysis followed by a detailed presentation of the results. The final section contains the summary and conclusions.

\section{Possible types of debt reductions}

In addition to the redistribution and the allocation function, one of the most important tasks of the modern state is to promote economic stability (Musgrave 1959). As part of this, one of the most significant requirements for fiscal policy is to be able to provide fiscal stimulus in crisis situations (such as a demand shortage) (Tóth 2010), i.e. to make available external financial sources through the general government (Alesina et al. 2008). As this is mostly achieved through government borrowing, the traditional view is that fiscal stimuli are generally accompanied by an increase in government debt.

This view was refined by De Grauwe - Ji (2019), who - based on the example of the EU15 - gave evidence supported by statistical data that in countries where the interest rate exceeds the GDP growth rate, the possibilities for fiscal expansion are limited due to the rise in the government debt ratio. However, where the interest rate is lower than GDP growth, the government debt ratio can be stabilised or reduced even with fiscal stimulus. Of course, the starting position, i.e. the initial value of the government debt ratio, is also significant: the higher it is, the more limited is the space for fiscal easing.

As a general trend, in order for the government to have enough fiscal space for indebtedness, if need be, it must be able to reduce the government debt ratio between crises, especially during economic recovery. On the one hand, this is necessary because if the government does not reduce the debt ratio in the recovery phase of the business cycle, then the so-called ratchet effect can easily occur ( $P$. Kiss 2012). This means that if the debt ratio rises in crisis, whereas in non-crisis periods it simply does not go up further, then indebtedness will continue to mount in the long run due to crisis-related increases, threatening the sustainability of the general government (Balatoni 2015, Tóth 2011). However, in a dynamically growing economy, a tight or more responsible fiscal policy is needed with a gradual reduction 
of the government debt ratio to create space for fiscal manoeuvre, even in the short term. Investor confidence gained in "peacetime" is an essential condition for meeting soaring financing needs in a crisis (Ghosh et al. 2013).

Lehmann et al (2020) also pointed out that the conditions for enforcing the convergence criteria set out in the Maastricht Treaty have recently become more difficult due to the decline in the rate of economic growth and inflation compared to the beginning of the 1990s. According to Nagy et al (2020), to stabilise the 60 per cent government debt ratio, the general government deficit relative to GDP should be 1.1 per cent instead of 3 per cent. Lehmann et al (2020) also pointed out that EU fiscal rules ignore the equilibrium requirements between major national economy sectors (non-bank private sector, government and the rest of the world).

In countries with high government debt values, reducing the government debt ratio in the recovery phase of the business cycle is an overall objective, the realisation of which significantly reduces the vulnerability of public finances and improves the resilience of the economy to the effects of the next economic crisis. There are several different ways to reduce the debt ratio, and they can and should be categorised in several ways. Based on the economic policy approach of Bernardini et al. (2019), we have created groups as follows:

i. Improvement in the primary balance. The academic literature generally refers to this channel as "orthodox fiscal adjustment" based on tax increases and expenditure restraints. The key question in this regard is how such a fiscal adjustment will affect economic growth and the level of interest rates and, through these two factors, the debt ratio itself. The general experience is that, in the short run, the rate of real GDP growth mostly declines due to the demand effect. However, the debt-increasing effect of this may be mitigated by fiscal discipline, which contributes to a moderation in nominal interest rates by strengthening investor confidence (Alesina-Perotti 1995, Alesina-Perotti 1997).

ii. Growth effect. Economic growth helps reduce debt through two channels. On the one hand, it lowers the debt ratio through the denominator effect. On the other hand, a booming economy generates more tax revenues, which also pushes down the debt ratio through the primary balance, if the additional revenues are not spent by the government but saved. From the point of view of measurement, however, it is often difficult to quantify the second effect. This would, namely, require accurate knowledge of the impact of economic growth on the budget balance, while filtering out the reverse effect. Although there was promising research on this (Mauro - Zilinsky 2016), when examining the change in the debt ratio, and thus when conducting the debt decomposition analyses as well, usually only the effect through the denominator is classified in this category. 
iii. Acceleration of inflation. According to mainstream economic theories, in today's practice, raising the money supply is less common but it is a theoretically possible way to monetise government debt. The financial theories of recent years (endogenous money creation) reject this approach. In this context, we refer to an increase in the inflation rate rather than in the money supply (because the latter does not necessarily induce the price level to rise). Growth in the price level through real interest rates in itself diminishes the debt ratio, but only if there is surprise inflation, and only to the extent that the given government relies on long-term, fixed-interest loans for financing (Aizenman - Marion 2009). Although to a lesser extent, an acceleration in the rate of inflation (or GDP deflator) may also help reduce the debt ratio through the denominator effect, because the larger the nominal GDP becomes, the smaller the quotient is (Hall - Sargent 2010).

iv. Decline in interest rates. A decline in interest rates, both nominal and real, will reduce the debt ratio. In the former case, the interest expenditures constituting part of the annual current expenditures of government debt fall. One important tool for interest rate reduction is so-called financial repression (Reinhart - Rogoff 2009, Reinhart 2012). All legal and other administrative instruments aimed at cutting the interest rate level of government borrowing can be classified here. This may include the maximisation of deposit rates competing with government bonds enacted by the regulator, as well as the mandatory prescription to purchase a certain amount of government bonds for different insurance undertakings. In addition, the interest burden can also be reduced by restructuring government debt if a country succeeds in exchanging its government bonds for securities with lower interest rates or longer maturities. The last example in Europe was in Greece (Györffy 2014). A similar procedure is so-called mutualisation, which has been coined in the European Union typically, aiming to replace market loans with funds through the financing by EU institutions. These would raise funds from the market at a much lower rate than the market rates, due to the joint guarantee. The scheme was first a stopgap solution to manage the sovereign debt crisis. It was later put on the agenda in the context of further development of the Economic and Monetary Union with the aim of issuing government bonds jointly guaranteed by the Member States. Adoption of the proposal is unlikely, mainly due to Germany's opposition.

v. Privatisation. One of the classic forms of debt reduction is the sale of state property. The key question in this respect is whether the state has assets that can be managed more efficiently in private ownership. The effectiveness and impact of privatisation measures depend largely on the price at which the transaction takes place. In most of the sample countries we analysed, this impact was negligible. 
vi. Exchange rate effect. Government debt can also be lowered if the exchange rate of the domestic currency strengthens. The extent of this mainly depends on the amount of foreign currency liabilities within government debt. Through the exchange rate effect, not only the value of the debt can be mitigated, as annual nominal interest costs can also be lowered at the same time.

\section{Evolution of government debt ratios}

In this section, we present a detailed overview of the evolution of the government debt ratio of the EU15 countries in the period before the Great Recession and in the debt reduction period that ended in 2019. The first phase covers the period from 1997 to 2007 and the second one from 2015 to 2019 (Figure 1). In both cases, the first and last year of the decline in the average debt ratio constitute the time frame. For each country, the beginning and end of the debt reduction periods may also vary related to each phase. As the average government debt ratio rose between 2008 and 2014, we did not cover this, except of those countries where the second debt reduction period started in these years. Thus, during the analysis of each countries the first period is the period before the global financial crisis, while the second period is the 2010s.

To ensure the comparability of the data, we used the European Commission's AMECO database, both for the descriptive statistics and the subsequent analysis of debt dynamics. Most of the data series are available from 1995 and the last year taken into account in the calculations is 2019. As actual data for 2019 were not yet published at the time of writing the study, we used the latest EU forecast ${ }^{5}$ available for download from the AMECO database. ${ }^{6}$

In terms of government debt relative to GDP, between 1997 and 2019, the two debt reduction periods are separated by a dynamic phase of increase in the debt ratio. In the mid-1990s, the average government debt ratio in the country group was 70 per cent, which fell from that level to 56 per cent by 2007. During this period, there were four countries (Greece, France, Germany and Portugal) with increasing government debt ratios. However, the increase typically did not exceed 10 percentage points even in these states. By contrast, between 1997 and 2007, for example, government debt relative to GDP fell by 46 percentage points in Ireland, 41 percentage points in Belgium and 30 percentage points in both the Netherlands and Sweden.

\footnotetext{
${ }^{5}$ As for Denmark, AMECO contains data on debt only from 2000 onwards, and Danish data were not taken into account for longer data series aggregated at country group level. However, the debt decomposition analysis was, of course, also performed for Denmark in the shorter time series.

${ }^{6}$ Date of downloading the data: 9 October 2019
} 
As a consequence of the international financial and economic crisis and the resulting sovereign debt crisis in the euro area, the EU15 government debt ratio rose to 92 per cent by the end of 2014 and fell from there to 83 per cent at the end of 2019, according to the European Commission's forecast. During this period, the debt ratio only rose in France and Italy, but by only a few percentage points. At the same time, government debt relative to GDP decreased by 43 percentage points in Ireland, 19 percentage points in the Netherlands and 17 percentage points in Germany between 2015 and 2019.

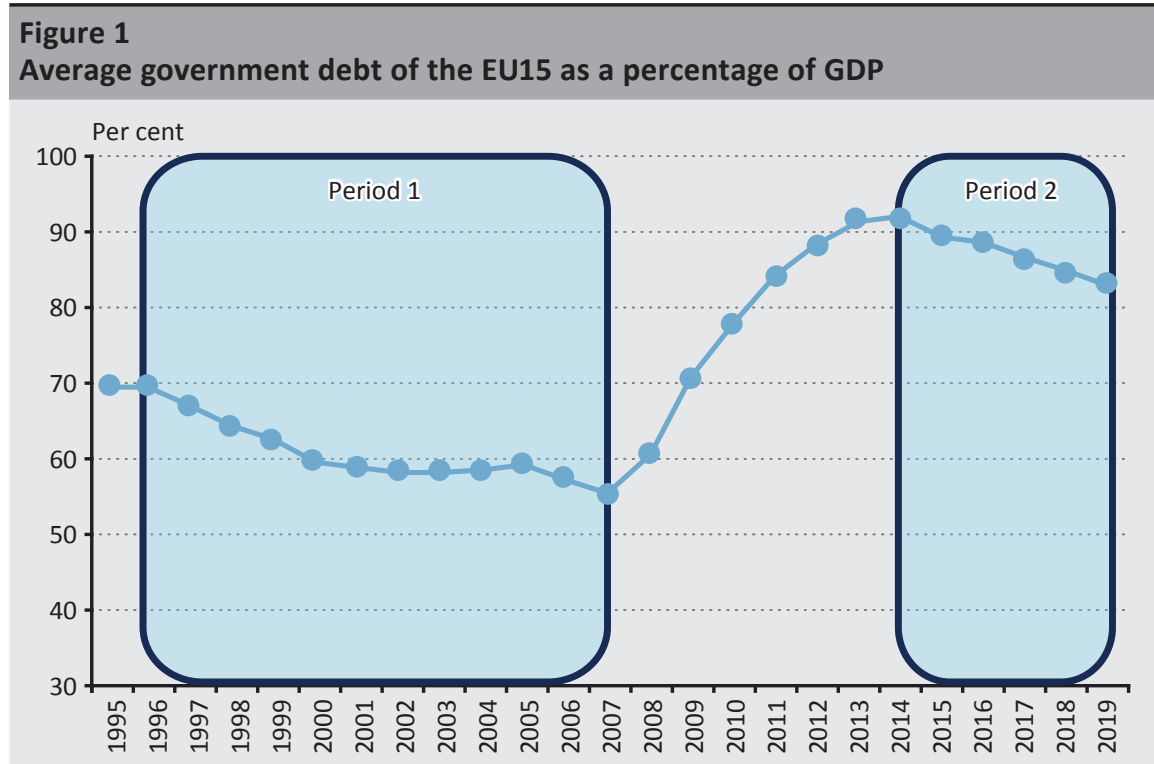

Source: $A M E C O$

Although there are many similarities in the dynamics of the debt ratio between the countries reviewed, the differences in the level of the indicator are significant throughout the period (as well). In the first period, the government debt ratio was exceptionally high in three countries - Belgium, Italy and Greece - where it exceeded 100 per cent of GDP. As a result of the crisis, the Greek debt ratio jumped quickly above 160 per cent and the Italian and Portuguese indicators to 130 per cent. At the other end of the scale, on the one hand, it is worth highlighting Luxembourg, where the government debt ratio was below 25 per cent all along, and on the other hand Sweden, which was closest to it, where the value of the indicator was still around 70 per cent in the mid-1990s, which in turn has fallen below 40 per cent in recent years.

Giving a bird's eye view summary of the most important characteristics of the two debt reduction periods for the whole group of countries, it can be stated 
that whereas in the first period of 1997-2007 the average government debt ratio dropped by around 1 percentage point on average per year, starting from an average of around 70 per cent, in the second period of 2015-2019 it declined from more than 90 per cent by nearly two percentage points per annum. In the next section, we analyse the components of this.

\section{Debt decomposition analysis}

\subsection{The roadmap of decomposition}

For decades, there has been a very significant emphasis in the academic literature on identifying the factors influencing changes in government debt and on accurately quantifying each effect. Although there has been continuous innovations in terms of methodology (see Mauro - Zilinsky 2016), it has been true for a relatively long time that most analyses try to estimate the effects using either a VAR model (Hasko 2007, Cherif - Hasanov 2010, Ábel - Kóbor 2011), or perform the decomposition with a so-called debt dynamics analysis (P. Kiss 1999, De Bolle et al. 2006, HallSargent 2010).

The advantage of the former method is that in quantifying each effect, it is possible to control for all other factors (balance, interest rate, economic growth), and we are free to choose which factors we want to analyse in terms of their effects. It is important to emphasise that this is an estimation procedure that in itself carries considerable uncertainty. A reliable estimate would require a long time series, which is often not available.

The debt dynamics analysis we use below is based on accounting equivalences and is reproducible because neither the length of the period under review nor other circumstances affect the results. In the following, we deduce the decomposition of changes in the debt ratio, based on the works of $R a-$ Rhee (2005) and Escolano (2010).

In the debt dynamics analysis, we used the assumption that the development of nominal government debt is influenced by the nominal interest rate and the primary balance. All other factors (such as the effect of exchange rate changes) can be classified in the category of other items. In contrast to inflation, both the nominal and the real interest rate are forward-looking, i.e. the debt (change) in period $t$ depends (also) on the interest rate in period $t-1$ :

$$
B_{t}=\left(1+i_{t-1}\right) B_{t-1}-P B_{t}+S F A_{t},
$$

where $B_{t}$ is the nominal government debt in period $t, i_{t-1}$ is the nominal interest rate of the previous year, $P B_{t}$ is the primary balance and $S F A_{t}$ is the other item (stockflow adjustment). As government debt is typically defined as a percentage of gross domestic product, we divide both sides by the GDP in period $t\left(Y_{t}\right)$ : 


$$
\frac{B_{t}}{Y_{t}}=\frac{\left(1+i_{t-1}\right) B_{t-1}}{Y_{t}}-\frac{P B_{t}}{Y_{t}}+\frac{S F A_{t}}{Y_{t}}
$$

and we express $Y_{t}$ by means of $Y_{t-1}$ :

$$
\frac{B_{t}}{Y_{t}}=\frac{\left(1+i_{t-1}\right) B_{t-1}}{\left(1+g_{t}\right)\left(1+\pi_{t}\right) Y_{t-1}}-\frac{P B_{t}}{Y_{t}}+\frac{S F A_{t}}{Y_{t}}
$$

where real growth is $g_{t}$ and inflation is $\pi_{t}$.

Indicators relative to GDP are denoted in lower-case letters. Accordingly, the government debt is $b_{t}$, the primary balance is $p b_{t}$ and the other item is $s f a_{t}$.

$$
c=\frac{\left(1+i_{t-1}\right)}{\left(1+g_{t}\right)\left(1+\pi_{t}\right)} b_{t-1}-p b_{t}+s f a_{t}
$$

In the next step, we subtract the $t-1^{\text {th }}$ periodic debt ratio from both sides of the equation and obtain the change in the debt ratio:

$$
\begin{aligned}
& \Delta b_{t}=\frac{\left(1+i_{t-1}\right)}{\left(1+g_{t}\right)\left(1+\pi_{t}\right)} b_{t-1}-b_{t-1}-p b_{t}+s f a_{t} \\
& \Delta b_{t}=\left[\frac{\left(1+i_{t-1}\right)}{\left(1+g_{t}\right)\left(1+\pi_{t}\right)}-1\right] b_{t-1}-p b_{t}+s f a_{t} \\
& \Delta b_{t}=\left[\frac{\left(1+i_{t-1}\right)}{\left(1+g_{t}\right)\left(1+\pi_{t}\right)}-\frac{\left(1+g_{t}\right)\left(1+\pi_{t}\right)}{\left(1+g_{t}\right)\left(1+\pi_{t}\right)}\right] b_{t-1}-p b_{t}+s f a_{t} \\
& \Delta b_{t}=\left[\frac{\left(1+i_{t-1}\right)-\left(1+g_{t}\right)\left(1+\pi_{t}\right)}{\left(1+g_{t}\right)\left(1+\pi_{t}\right)}\right] b_{t-1}-p b_{t}+s f a_{t} \\
& \Delta b_{t}=\left[\frac{\left.i_{t-1}-g_{t}-\pi_{t}-g_{t} \pi_{t}\right)}{\left(1+g_{t}\right)\left(1+\pi_{t}\right)}\right] b_{t-1}-p b_{t}+s f a_{t}
\end{aligned}
$$

On the right side of equation (10), we can find the decomposition of the change in the debt ratio for the following items in the order listed below:

- real GDP growth,

- nominal interest rate,

- inflation rate,

- primary budget balance,

- other items (privatisation, exchange rate, etc.) 
In order to be able to interpret the results properly, it is worth drawing attention to a few more things. On the one hand, if we add the positive effect of the nominal interest rate and the negative effect of inflation, we get the effect of the real interest rate. This is important because the dynamic component, or as it is otherwise called, the snowball effect, which is the combined effect of the real interest rate and real GDP growth, plays a prominent role in the academic literature. The dynamic component is important because its sign determines whether the primary balance should show a surplus to stabilise the debt ratio, if the sum of the other effects is assumed to be zero. In addition, the difference between real GDP growth and the real interest rate is very often used to measure the sustainability of debt dynamics (Mellár 2002).

It can also be added to the interpretation of equation (10) that - since this is a method based on static accounting equivalences - the effect of the primary balance includes the improvement in the balance due to the acceleration of real GDP growth and the deterioration due to the slowdown or absence of real GDP growth. As to the growth effect, it includes the effects of fiscal demand stimulus and demand contraction. In other words, this method can only measure direct effects: on the one hand, the extent to which the government increases or decreases the debt by a primary deficit or by a primary surplus from year to year, and on the other hand, how real GDP growth affects the debt ratio through the denominator. Other effects are calculated in accordance with international practice covered by the academic literature. This comprises the effects of all factors that are not included in the others (privatisation, exchange rate effect, etc.).

\subsection{The parameters of the debt decomposition analysis}

The objective of the debt dynamics analysis is to identify, based on the presented methodology, which of the listed factors has influenced the development of the government debt ratio, and to what extent. We did not cover the whole period and all the countries, but only the years and countries when and where the government debt ratio declined. This means that we defined a pre-crisis and a post-crisis debt reduction period, if any, for each country. These debt reduction periods had to meet the following conditions:

- Government debt relative to GDP has been shrinking steadily for at least three years.

- During the debt reduction period, the government debt ratio declines by at least 0.5 per cent of GDP on average per year.

- During the debt reduction period, the government debt relative to GDP has fallen by at least 3 percentage points.

- In the debt reduction period, there are at most two years when the debt ratio does not decrease, but even then, the rise in the indicator is no greater than 20 per cent of the contraction that has occurred throughout the period. 
In the first period, 11 of the 15 old EU Member States had a debt reduction phase meeting the above conditions. Of the countries under survey, only Greece, Austria, Germany and Luxembourg did not meet these criteria.

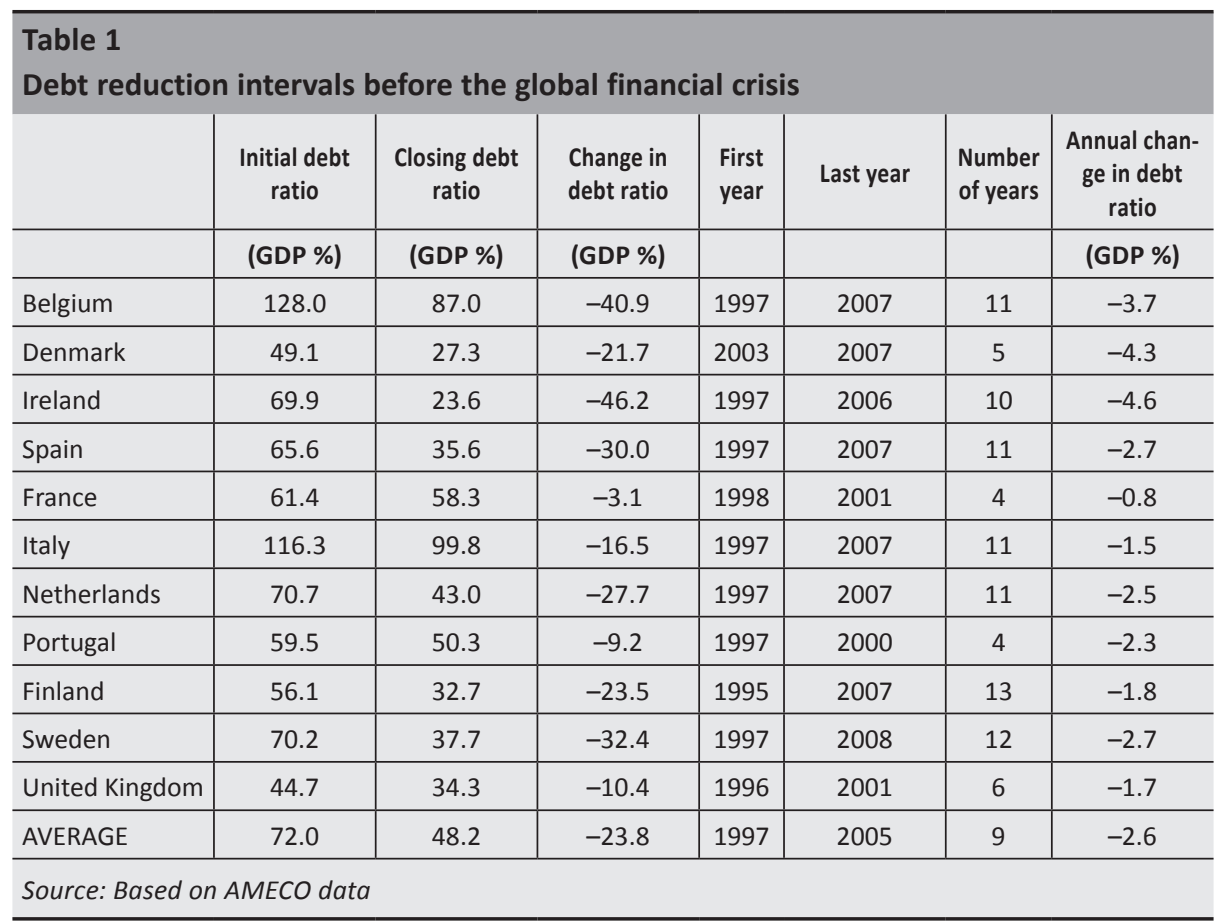

There were significant differences in all dimensions between debt reduction periods in terms of both time sequencing and the extent of debt reduction (Table 1). At the beginning of the 11 debt reduction periods of the 11 countries included in the analysis, the average government debt ratio was 72.0 per cent, which fell by 23.8 percentage points to 48.2 per cent on average by the end of the period. The largest debt ratio reduction amounted to almost 50 percentage points in Ireland, but it also exceeded 40 percentage points in Belgium, whereas the smallest reduction totalling 3.1 percentage points took place in France.

Debt reduction started typically before 1998. The only exception was Denmark, where it commenced in 2003. Debt reduction typically ended with the introduction of the euro beginning in 1998 and with the outbreak of the global financial and economic crisis. Prior to the introduction of the euro, the countries concerned met the convergence requirement for government debt. After the implementation of the Economic and Monetary Union, however, this pressure temporarily eased. The government debt reduction period was the longest in Finland, at 13 years, and the shortest in Portugal and France, at 4 years, while the average was 9 years. 
In terms of the size of debt reduction per year, Ireland and Denmark were in first place with 4.6 and 4.3 percentage points, respectively, followed by France at the back of the ranking with 0.8 percentage points (Table 1). In the 11 years of the first period, government debt relative to GDP contracted by an average of 2.6 percentage points annually.

In the second period, ten countries had a debt reduction period meeting the conditions outlined above. Italy, France, Greece, Luxembourg and the United Kingdom were the exceptions (Table 2). In the starting year, the average debt ratio was 84.8 per cent, which fell by 16.6 percentage points to 68.1 per cent. The best performer was Ireland with 58.6 percentage points, Germany was second in the ranking with 23.4 percentage points, whereas the smallest debt ratio reduction of 4.1 percentage points took place in Spain.

\section{Table 2}

Debt reduction intervals in the 2010s

\begin{tabular}{l|c|c|c|c|c|c|c} 
& $\begin{array}{c}\text { Initial debt } \\
\text { ratio }\end{array}$ & $\begin{array}{c}\text { Closing debt } \\
\text { ratio }\end{array}$ & $\begin{array}{c}\text { Change in } \\
\text { debt ratio }\end{array}$ & $\begin{array}{c}\text { First } \\
\text { year }\end{array}$ & Last year & $\begin{array}{c}\text { Number } \\
\text { of years }\end{array}$ & $\begin{array}{c}\text { Annual chan- } \\
\text { ge in debt } \\
\text { ratio }\end{array}$ \\
\hline Belgium & 107.5 & 101.3 & -6.2 & 2015 & 2019 & 5 & -1.2 \\
\hline Denmark & 46.1 & 33.0 & -13.1 & 2012 & 2019 & 8 & -1.6 \\
\hline Germany & 81.8 & 58.4 & -23.4 & 2011 & 2019 & 9 & -2.6 \\
\hline Ireland & 119.9 & 61.3 & -58.6 & 2013 & 2019 & 7 & -8.4 \\
\hline Spain & 100.4 & 96.3 & -4.1 & 2015 & 2019 & 5 & -0.8 \\
\hline Netherlands & 67.9 & 49.1 & -18.8 & 2015 & 2019 & 5 & -3.8 \\
\hline Austria & 84.7 & 69.7 & -15.0 & 2016 & 2019 & 4 & -3.8 \\
\hline Portugal & 130.6 & 119.5 & -11.1 & 2015 & 2019 & 5 & -2.2 \\
\hline Finland & 63.4 & 58.3 & -5.1 & 2016 & 2019 & 4 & -1.3 \\
\hline Sweden & 45.5 & 34.4 & -11.1 & 2015 & 2019 & 5 & -2.2 \\
\hline AVERAGE & 84.8 & 68.1 & -16.6 & 2014 & 2019 & 6 & -2.8 \\
\hline Source: Based on AMECO data & & & & & & \\
\hline
\end{tabular}

Post-crisis debt reduction typically started around 2015, but commenced as early as 2011 in Germany, while it only began in 2016 in Finland and Austria. The last year analysed is 2019 , not only because the current figures for this year are likely to no longer deviate substantially from the final values, but because Covid-19 pandemic will terminate this consolidation period as well. Accordingly, the average length of the debt reduction periods was 6 years. Ireland also leads in the one-year debt reduction with 8.4 percentage points, followed well behind by the Netherlands and Austria with 3.8 percentage points each, whereas Spain finds itself at the back of the 
ranking with 0.8 percentage points. The average annual debt reduction for the entire second period and all debt reduction intervals until 2019 was 2.8 per cent of GDP.

Summarising the above, the most important similarity between the two periods is that, on the one hand, in both periods the same number of countries (on the order of 10-11) had debt reduction intervals, and on the other hand, the rate of average annual debt ratio decline was also similar (2.6 and 2.8 percentage points, respectively).

There was no significant difference in the initial level of debt ratios, which averaged 72 per cent in the first period and 85 per cent in the second one. However, at the end of the debt reduction periods, the difference was greater. In light of the similar pace of debt reduction, this can be attributed to the different lengths of the two periods analysed ( 9 and 6 years, respectively).

\section{Results}

\subsection{Average effects}

In the following, we first provide details as to what extent the listed factors by country contributed to debt reduction separately in the two periods analysed, and then we compare the two periods on the basis of the relative contribution of each factor.

With respect to the first period, it can be generally stated that the driving force in debt reduction was exclusively fiscal policy and, within that, fiscal discipline (Table 3). Namely, the average debt reduction effect of the primary balance $(29.5$ percentage points) exceeded the average debt reduction rate (23.8 percentage points). This also holds true for almost two-thirds of the countries individually, but is particularly valid for Finland, where the debt-reducing effect of the primary balance was almost three times the debt ratio decline. Portugal was the only country where the primary deficit raised the debt level even during the debt reduction period. In the other countries analysed, fiscal policy not only helped to reduce liabilities but led the way in this process as well. 


\begin{tabular}{|c|c|c|c|c|c|c|c|c|}
\hline \multicolumn{9}{|l|}{ Table 3} \\
\hline & \multirow[t]{2}{*}{$\begin{array}{c}\text { Change in } \\
\text { debt }\end{array}$} & $\begin{array}{l}\text { Primary } \\
\text { balance }\end{array}$ & $\begin{array}{l}\text { Real GDP } \\
\text { growth }\end{array}$ & Inflation & $\begin{array}{c}\text { Nominal } \\
\text { interest rate }\end{array}$ & Other items & Snowball & $\begin{array}{c}\text { Real interest } \\
\text { rate }\end{array}$ \\
\hline & & (1) & (2) & (3) & (4) & (5) & $(2)+(3)+(4)$ & $(3)+(4)$ \\
\hline Belgium & -40.9 & -55.8 & -29.0 & -21.3 & 68.0 & -2.8 & 17.7 & 46.7 \\
\hline Denmark & -21.7 & -27.6 & -4.0 & -3.5 & 10.4 & 3.1 & 2.8 & 6.9 \\
\hline Ireland & -46.2 & -36.6 & -29.1 & -12.3 & 15.0 & 16.7 & -26.3 & 2.7 \\
\hline Spain & -30.0 & -24.6 & -21.6 & -16.4 & 29.0 & 3.6 & -9.0 & 12.7 \\
\hline Italy & -16.5 & -31.8 & -17.4 & -25.1 & 63.9 & -6.1 & 21.4 & 38.8 \\
\hline Netherlands & -27.7 & -22.6 & -17.4 & -12.7 & 31.9 & -6.9 & 1.8 & 19.2 \\
\hline Portugal & -9.2 & 1.4 & -8.6 & -5.3 & 12.5 & -9.1 & -1.5 & 7.1 \\
\hline Finland & -23.5 & -64.3 & -23.2 & -9.3 & 35.0 & 38.3 & 2.6 & 25.8 \\
\hline Sweden & -32.4 & -44.0 & -20.0 & -7.7 & 32.9 & 6.4 & 5.2 & 25.2 \\
\hline $\begin{array}{l}\text { United } \\
\text { Kingdom }\end{array}$ & -10.4 & -12.5 & -7.8 & -4.7 & 17.1 & -2.4 & 4.5 & 12.4 \\
\hline France & -3.1 & -5.7 & -7.5 & -2.7 & 13.2 & -0.5 & 3.0 & 10.5 \\
\hline AVERAGE & -23.8 & -29.5 & -16.9 & -11.0 & 29.9 & 3.6 & 2.0 & 18.9 \\
\hline
\end{tabular}

Unlike disciplined fiscal policy, the snowball effect did not make a substantial contribution to reducing the debt ratio. Regarding the average trends, the debtreducing effect of real GDP growth was just offset by the effect of the real interest rate. In this respect, however, there are larger differences between the individual countries. The snowball effect increased the debt ratio in Italy and Belgium by nearly 20 percentage points due to high interest rates, while it reduced it by nearly 10 percentage points in Spain and by nearly 30 percentage points in Ireland. It is true for both of the latter countries that the debt-reducing effect of economic growth surpassed the average, whereas the debt-increasing effect of the real interest rate fell short of it. Like the snowball effect, the other items did not substantially affect the debt ratio on average for the countries analysed. Finland and Ireland can be mentioned as exceptions, where the government debt ratio rose by 38 and 17 percentage points, respectively.

As the debt reduction period in each country was different in length, it is also worth examining the decomposition per annum (Table 4). This shows that fiscal policy supported the debt ratio decline - by more than 5 percentage points per year - in Belgium and Denmark, whereas in Portugal the rate of reduction was 0.2 percentage 
points annually. In the case of Ireland and Belgium, which are at the forefront of real GDP growth, the contribution of economic growth was 2.5-3 percentage points per year, whereas in Denmark it was only 0.8 percentage points. The real interest rate lifted government debt relative to GDP by only 0.3 percentage points per annum in Ireland, compared to 4.2 percentage points in Belgium. The other items raised the debt ratio by almost 3 percentage points per year in Finland and 1.7 percentage points per year in Ireland, whereas they reduced it by more than 2 percentage points in Portugal.

\section{Table 4}

Decomposition of the change in debt ratio on an annual average basis, as a percentage of GDP, before the global financial crisis

\begin{tabular}{|c|c|c|c|c|c|c|c|c|}
\hline & $\begin{array}{c}\text { Change in } \\
\text { debt }\end{array}$ & $\begin{array}{l}\text { Primary } \\
\text { balance }\end{array}$ & $\begin{array}{l}\text { Real GDP } \\
\text { growth }\end{array}$ & Inflation & $\begin{array}{c}\text { Nominal } \\
\text { interest rate }\end{array}$ & Other items & Snowball & $\begin{array}{c}\text { Real interest } \\
\text { rate }\end{array}$ \\
\hline & & (1) & (2) & (3) & (4) & (5) & $(2)+(3)+(4)$ & $(3)+(4)$ \\
\hline Belgium & -3.7 & -5.1 & -2.6 & -1.9 & 6.2 & -0.3 & 1.6 & 4.2 \\
\hline Denmark & -4.3 & -5.5 & -0.8 & -0.7 & 2.1 & 0.6 & 0.6 & 1.4 \\
\hline Ireland & -4.6 & -3.7 & -2.9 & -1.2 & 1.5 & 1.7 & -2.6 & 0.3 \\
\hline Spain & -2.7 & -2.2 & -2.0 & -1.5 & 2.6 & 0.3 & -0.8 & 1.2 \\
\hline Italy & -1.5 & -2.9 & -1.6 & -2.3 & 5.8 & -0.6 & 1.9 & 3.5 \\
\hline Netherlands & -2.5 & -2.1 & -1.6 & -1.2 & 2.9 & -0.6 & 0.2 & 1.7 \\
\hline Portugal & -2.3 & 0.4 & -2.2 & -1.3 & 3.1 & -2.3 & -0.4 & 1.8 \\
\hline Finland & -1.8 & -4.9 & -1.8 & -0.7 & 2.7 & 2.9 & 0.2 & 2.0 \\
\hline Sweden & -2.7 & -3.7 & -1.7 & -0.6 & 2.7 & 0.5 & 0.4 & 2.1 \\
\hline $\begin{array}{l}\text { United } \\
\text { Kingdom }\end{array}$ & -1.7 & -2.1 & -1.3 & -0.8 & 2.8 & -0.4 & 0.8 & 2.1 \\
\hline France & -0.8 & -1.4 & -1.9 & -0.7 & 3.3 & -0.1 & 0.8 & 2.6 \\
\hline AVERAGE & -2.7 & -3.3 & -1.9 & -1.2 & 3.4 & 0.4 & 0.2 & 2.1 \\
\hline
\end{tabular}

Source: Calculations based on AMECO data

We get a different picture by analysing the 10 debt reduction intervals that took place in the second period. According to the debt dynamics analysis, just over onethird of the average debt ratio reduction of 16.6 per cent (6.1 percentage points on average) is explained by fiscal policy (Table 5). There is no country where the effect of the primary surplus exceeds the overall debt ratio reduction. Fiscal policy enhanced the debt ratio in Spain and did not substantially lower it in Ireland and Finland. 


\begin{tabular}{|c|c|c|c|c|c|c|c|c|}
\hline \multicolumn{9}{|l|}{$\begin{array}{l}\text { Table } 5 \\
\text { Decompc }\end{array}$} \\
\hline & \multirow[t]{2}{*}{$\begin{array}{c}\text { Change in } \\
\text { debt }\end{array}$} & $\begin{array}{l}\text { Primary } \\
\text { balance }\end{array}$ & $\begin{array}{l}\text { Real GDP } \\
\text { growth }\end{array}$ & Inflation & $\begin{array}{c}\text { Nominal } \\
\text { interest rate }\end{array}$ & Other items & Snowball & $\begin{array}{c}\text { Real interest } \\
\text { rate }\end{array}$ \\
\hline & & (1) & (2) & (3) & (4) & (5) & $(2)+(3)+(4)$ & $(3)+(4)$ \\
\hline Belgium & -6.2 & -5.1 & -7.7 & -8.8 & 15.9 & -0.5 & -0.6 & 7.1 \\
\hline Denmark & -13.1 & -8.6 & -5.0 & -3.1 & 11.5 & -7.9 & 3.4 & 8.4 \\
\hline Germany & -23.4 & -18.5 & -10.8 & -8.7 & 14.0 & 0.5 & -5.4 & 5.4 \\
\hline Ireland & -58.6 & -5.4 & -47.4 & -1.7 & 11.5 & -15.6 & -37.6 & 9.8 \\
\hline Spain & -4.1 & 4.4 & -13.9 & -3.9 & 15.4 & -6.2 & -2.3 & 11.6 \\
\hline Netherlands & -18.8 & -7.2 & -6.7 & -3.7 & 6.4 & -7.6 & -3.9 & 2.8 \\
\hline Austria & -15.0 & -5.2 & -6.8 & -5.4 & 7.9 & -5.6 & -4.2 & 2.6 \\
\hline Portugal & -11.1 & -9.1 & -12.8 & -5.7 & 17.0 & -0.5 & -1.5 & 11.3 \\
\hline Finland & -5.1 & -0.3 & -5.6 & -2.2 & 3.5 & -0.5 & -4.4 & 1.3 \\
\hline Sweden & -11.1 & -6.3 & -5.4 & -2.5 & 1.2 & 1.9 & -6.7 & -1.3 \\
\hline AVERAGE & -16.6 & -6.1 & -12.2 & -4.6 & 10.4 & -4.2 & -6.3 & 5.9 \\
\hline
\end{tabular}

On average, the snowball effect was almost exactly the same as the fiscal policy effect of around 6 percentage points. This means that in this period the debt ratioreducing effect of real GDP growth already exceeded the debt ratio-increasing effect of the real interest rate. In this respect, the position of Ireland is outstanding, because almost two-thirds of the debt ratio reduction can be attributed to the dynamic component. This is due to a very significant growth effect. The dynamic component was positive only in Denmark, which is related to a higher-than-average interest rate effect and a lower-than-average growth effect.

In addition to the primary balance and the snowball effect, the effect of the other items cannot be neglected either, as they reduced the debt ratio by an average of 4.2 percentage points. In this respect, Ireland also leads the list at -15.6 per cent (due to the privatisation of financial intermediaries rescued by the state during the international financial and economic crisis). In Sweden, however, the other items elevated the debt ratio substantially on the whole (mainly due to the exchange rate effect, i.e. the exchange rate depreciation of the Swedish krona against the euro).

When analysing debt reductions of the second period, it is also worth decomposing the change in debt ratio into years. This allows a more precise comparison of each country (Table 6). The comparison shows that in Denmark and Portugal the primary balance contributed the most to the decline in government debt ratio, by 2.1 and 
1.8 percentage points per year, respectively, whereas in Spain fiscal policy raised the debt ratio by nearly 1 percentage point on an annual average.

The annual effect of real GDP growth was by far the greatest in Ireland (-6.8 per cent), although it was also significant in Spain ( -2.8 per cent) and Portugal $(-2.6$ per cent). In Denmark, on the other hand, the increase in gross domestic product barely reduced the government debt ratio on an annual average.

The debt ratio-increasing effect of the real interest rate was largest in Spain and Portugal, totalling 2.3 percentage points per annum. As a result of the negative real interest rate, this item reduced the debt ratio in Sweden by 0.3 percentage point annually. The other items also supported Ireland the most on an annual average, by more than 2 percentage points, whereas in Sweden and Germany these items increased the debt ratio slightly each year.

\section{Table 6}

Decomposition of the change in debt ratio on an annual average basis, as a percentage of GDP, in the 2010 s

\begin{tabular}{l|c|c|c|c|c|c|c|c} 
& $\begin{array}{c}\text { Change in } \\
\text { debt }\end{array}$ & $\begin{array}{c}\text { Primary } \\
\text { balance }\end{array}$ & $\begin{array}{c}\text { Real GDP } \\
\text { growth }\end{array}$ & Inflation & $\begin{array}{c}\text { Nominal } \\
\text { interest rate }\end{array}$ & Other items & Snowball & $\begin{array}{c}\text { Real interest } \\
\text { rate }\end{array}$ \\
\cline { 3 - 9 } & & $\mathbf{( 1 )}$ & $\mathbf{( 2 )}$ & $\mathbf{( 3 )}$ & $\mathbf{( 4 )}$ & $\mathbf{( 5 )}$ & $\mathbf{( 2 ) + ( 3 ) + ( 4 )}$ & $\mathbf{( 3 ) + ( 4 )}$ \\
\hline Belgium & -1.2 & -1.0 & -1.5 & -1.8 & 3.2 & -0.1 & -0.1 & 1.4 \\
\hline Denmark & -1.6 & -1.1 & -0.6 & -0.4 & 1.4 & -1.0 & 0.4 & 1.0 \\
\hline Germany & -2.6 & -2.1 & -1.2 & -1.0 & 1.6 & 0.1 & -0.6 & 0.6 \\
\hline Ireland & -8.4 & -0.8 & -6.8 & -0.2 & 1.6 & -2.2 & -5.4 & 1.4 \\
\hline Spain & -0.8 & 0.9 & -2.8 & -0.8 & 3.1 & -1.2 & -0.5 & 2.3 \\
\hline Netherlands & -3.8 & -1.4 & -1.3 & -0.7 & 1.3 & -1.5 & -0.8 & 0.6 \\
\hline Austria & -3.8 & -1.3 & -1.7 & -1.3 & 2.0 & -1.4 & -1.1 & 0.6 \\
\hline Portugal & -2.2 & -1.8 & -2.6 & -1.1 & 3.4 & -0.1 & -0.3 & 2.3 \\
\hline Finland & -1.3 & -0.1 & -1.4 & -0.5 & 0.9 & -0.1 & -1.1 & 0.3 \\
\hline Sweden & -2.2 & -1.3 & -1.1 & -0.5 & 0.2 & 0.4 & -1.3 & -0.3 \\
\hline AVERAGE & -2.9 & -1.1 & -2.1 & -0.8 & 1.8 & -0.7 & -1.1 & 1.0
\end{tabular}

Source: Calculations based on AMECO data

\subsection{Average relative contributions}

Compared to the general characteristics, there are much more pronounced differences concerning the role of each item in reducing the debt ratio. The most significant difference is related to the budget (Figure 2). 


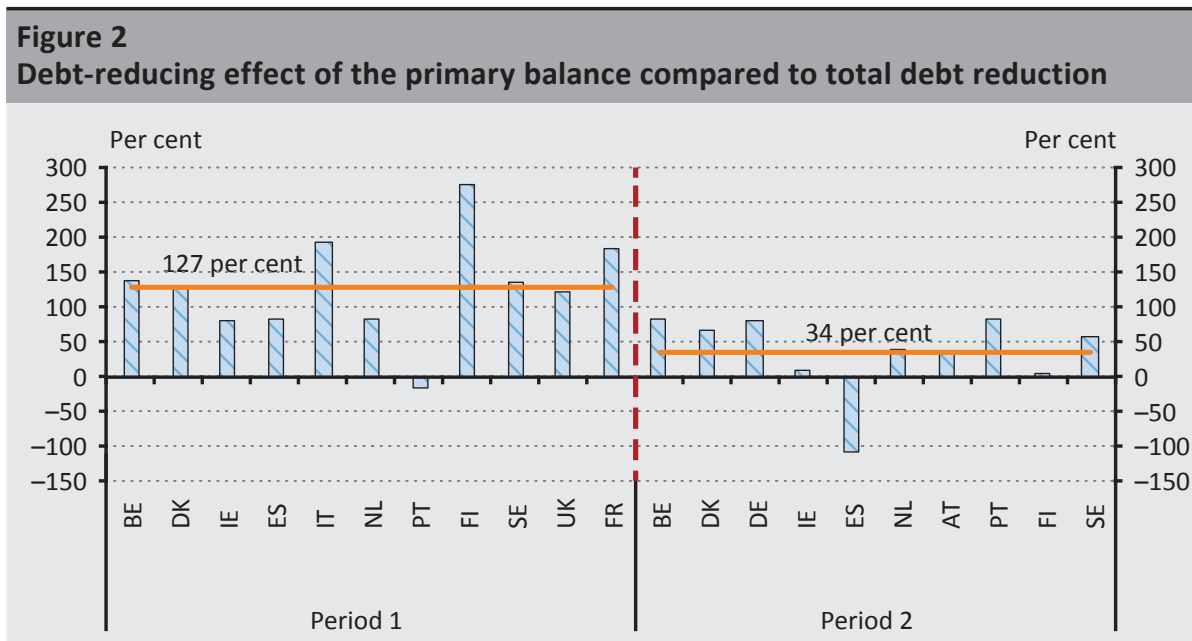

Note: The horizontal line is the average of the period. A positive value indicates contribution to debt reduction, a negative one represents the opposite effect.

Source: Calculations based on AMECO data

On average, the debt-reducing effect of the primary balance in the first period was 127 per cent of the total debt reduction, while in the second period it was only 34 per cent. In addition, all of this was not attributable to only one or two countries with outstanding results, but proved to be a general trend. In the first period, only one country (Portugal) did not reach the average of the second period, whereas in the second period no country approached that of the first one. It is, therefore, no exaggeration to conclude that, whereas before the crisis, the sole engine of debt reduction was disciplined fiscal policy, the role of the primary balance declined radically following the crisis.

In the two periods, the different function of fiscal policy in reducing the debt ratio obviously left its mark on other items as well. For example, the snowball effect (Figure 3) capturing the combined effect of the real interest rate and real GDP growth has the opposite sign in the two periods. In the first period preceding the crisis, the average snowball effect was -23 per cent. This means that the debt ratioincreasing effect of the real interest rate outweighed the opposite effect of real GDP growth, and therefore the snowball effect raised the debt. With three exceptions, this holds true for all countries. On the other hand, in the second period following the crisis, the snowball effect resulted in nearly one-third of the average debt ratio reductions. With the exception of one country, the debt ratio-reducing effect of real GDP growth was greater than that of the real interest rate everywhere (Figure 3 ). 


\section{Figure 3 \\ Debt reduction effect of the snowball effect compared to the total debt reduction}

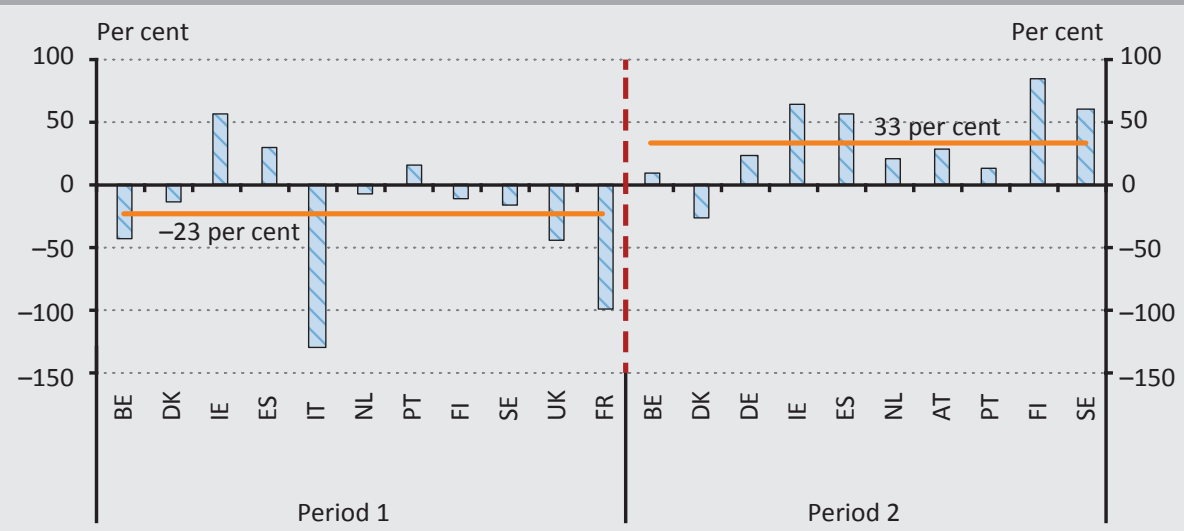

Note: The horizontal line denotes the average of the period. A positive value indicates contribution to debt reduction, a negative one represents the opposite effect.

Source: Calculations based on AMECO data

As for the effect of the other items, the difference is smaller compared to the above items, but also not negligible (Figure 4). In the first period, the other items contributed to the debt ratio reduction by an average of -4 per cent, i.e. their effect was practically neutral. In the second period, however, they became a major factor, contributing by an average of 32 per cent to the debt ratio reduction, i.e. similarly to the primary balance and snowball effects, they accounted for one-third of the debt reduction. Within this, the trends are well characterised by the fact that although there were differences between the individual states, the effect of the other items was positive everywhere, with one exception.

\section{Figure 4}

Debt-reducing effect of the other items compared to total debt reduction

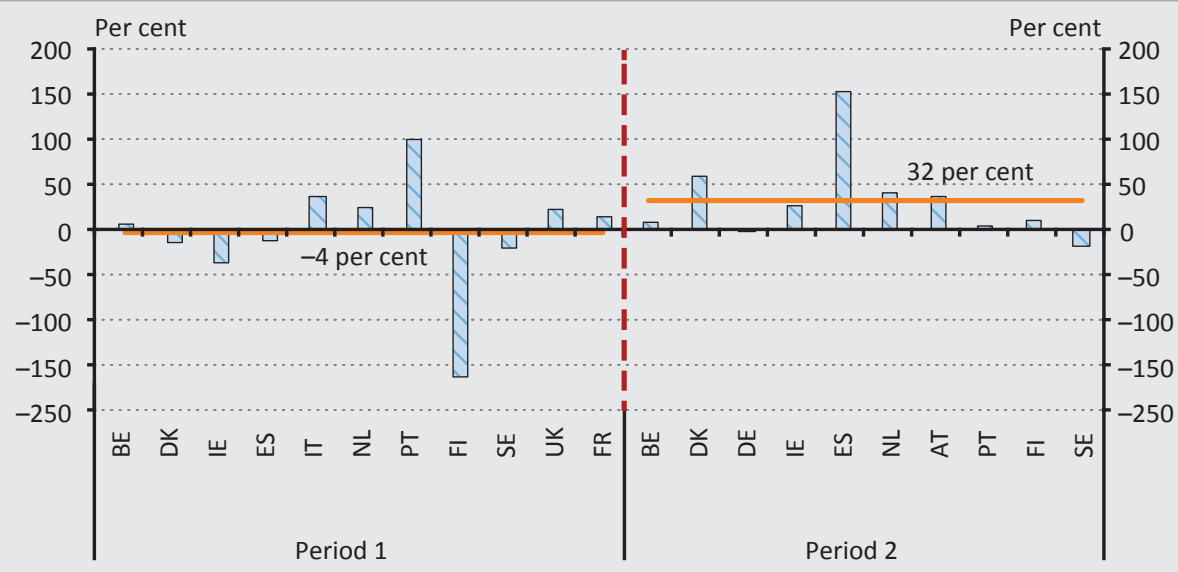

Note: The horizontal line denotes the average of the period.

Source: Calculations based on AMECO data 
If the average effect of each item is averaged separately each year, then it becomes clear to what extent the two debt reduction periods are similar and to what extent they differ (Figure 5). Among other things, the basis for the comparison is that whereas in the rate of annual debt ratio reduction there is barely a difference, the same cannot be said of the contribution of the individual items. In the first period, the primary balance reduced the debt ratio by an average of 3 percentage points per annum, while in the second period it decreased it by only 1 percentage point.

The snowball effect, before the crisis, lifted the debt ratio by 0.2 percentage point, but then, after the crisis it reduced it by 1 percentage point. It is worth emphasising, however, that within this there was no significant difference in the effect of real GDP growth. This item pushed down government debt relative to GDP by approximately 2 percentage points in both periods. The difference between dynamic components is due to the different effect of the real interest rate, which in turn can be attributed to the difference between the nominal interest rate and inflation.

\section{Figure 5}

Average effect of factors influencing the debt ratio as a percentage of GDP

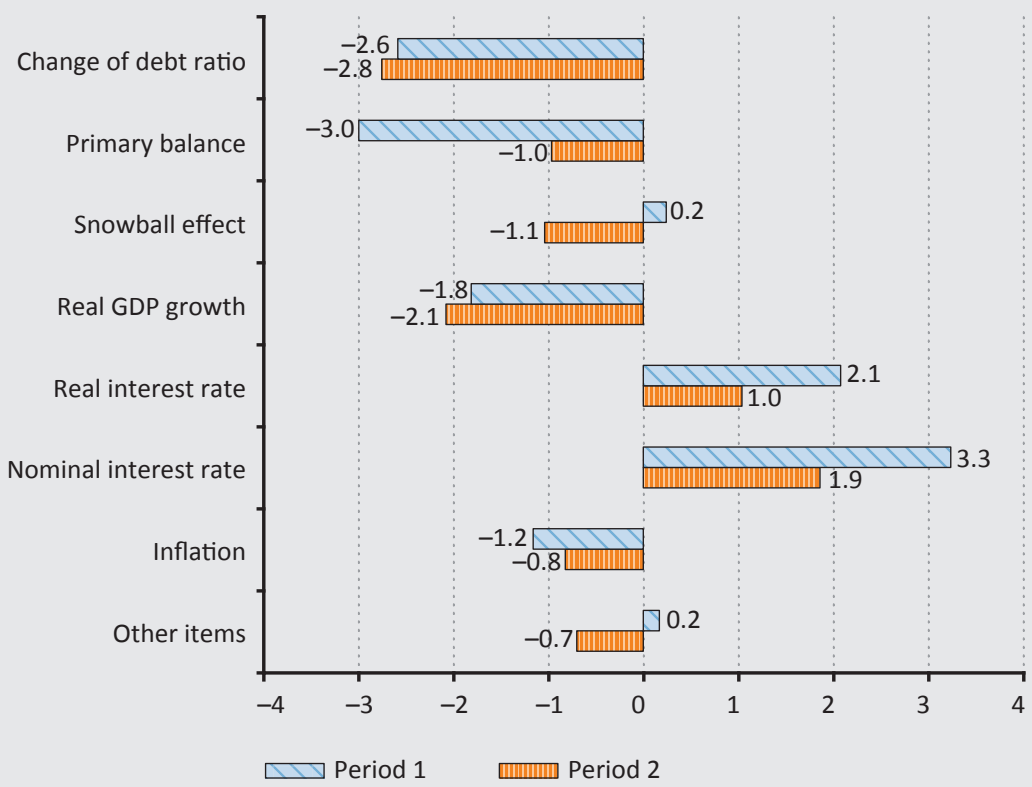

Source: Calculations based on AMECO data

In the first period, the debt-increasing effect of the nominal interest rate was 3.3 percentage points and the opposite effect of inflation was 1.2 percentage points. In the second period, the influence of the nominal interest rate was much smaller (1.9 percentage points) and that of inflation was only slightly lower ( -0.8 percentage 
point). This means that the effect of the real interest rate was stronger in the first period than in the second one, largely due to the influence of inflation which was not much greater in the first period than the effect of the nominal interest rate, compared to the second period. In other words, the post-crisis debt reduction is partly the result of nominal interest rates falling more than the inflation rate, and therefore, the debt-increasing effect of the real interest rate was smaller than before the crisis. By way of illustration, between 2010 and 2019 the one-year money market interest rate in the euro area declined to -0.19 per cent from an annual average of 3.92 per cent in 1996-2007.

Our results concerning the structure of debt reduction before the Great Recession are broadly in line with an earlier conclusion of the European Commission's 2010 publication (European Commission 2010). Although they analysed a shorter period (2003-2007) of fiscal policy for the entire euro area, they found that the effect of the primary balance was twice as large as the overall debt reduction, which was partly offset by the snowball effect and the sum of the other items. Another analysis by the organisation (European Commission 2018) also covered the entire euro area, but for a shorter period (2015-2018) than our paper. In this, like us, they calculated that one-half of the debt reduction implemented in the euro area countries in the second half of the 2010s is attributable to the snowball effect, more than one-third to the primary balance and nearly one-tenth to the other items.

\section{Summary and conclusions}

The reduction of the government debt ratio of the EU Member States until 2019, as well as its effectiveness and structure, has a significant, long-term effect not only on the development of public finances, but on GDP growth as well and, more broadly, on the general macroeconomic performance of the countries concerned as well. Therefore, it is worthwhile and instructive to learn as much as possible about the quality, structure and specific aspects of the reduction in government debt ratios. The objective of our analysis was to explore, quantify and evaluate the factors and trends behind the reduction in government debt ratios. The research method used was a comparative statistical analysis based on the sample of the 15 old Member States of the European Union.

It can be highlighted as a common feature of the debt ratio reduction in the first period (before the global financial crisis) and the second one (the 2010s) that nearly two-thirds of the countries analysed had a period when the government debt ratio had contracted by at least 3 percentage points for several years. At the beginning of the decline phases, the average initial level of the government debt ratios was 72 per cent in the first period and 85 per cent in the second period, whereas it was 48 and 68 per cent at the end of these two phases. The length of reduction 
averaged 9 years in the first period, but only 6 years in the second one. As a result, the rate of average annual debt ratio reduction was 2.8 percentage points in the first period and 2.6 percentage points in the second period, i.e. the pace was practically identical.

In our study, we used debt dynamics tools to answer the questions: which factors drove the moderation of the debt ratio at a similar rate on an annual average in the two periods and whether there were differences between the two apparently similar periods in this respect, and if so, what are they. Our main conclusion is that, in the first period, debt reduction was driven solely by tight, disciplined (restrictive) fiscal policy, whereas the real interest rate and real GDP growth taken together lifted the debt ratio slightly and the other factors did not substantially affect it. On the other hand, in the second period, the primary balance, the snowball effect and the sum of the other items contributed almost equally (one-third each) to the reduction in the debt ratio. It is important to point out that the effect of real GDP growth was the same in the two periods examined, and therefore the difference between snowball effects was due to the different effects of real interest rates. This, in turn, can be attributed to the fact that nominal interest rates were much lower in the second period than in the first one, whereas no such a difference was found between the inflation rates in the two periods.

In summary, it can be stated that in the first period the budget dynamised the reduction in the debt ratio, while in the second period the effect of fiscal policy weakened significantly, and the role of the lower interest rate level and the other items gained in importance. This suggests that in the second period, the reduction in the government debt ratio was fuelled more intensively by factors independent of fiscal policy, and thus, among other things, it depended heavily on loose monetary policy. Supportive monetary policy appears to have rendered fiscal policy complacent through low real interest rates. With a change in monetary conditions, this questions the long-term sustainability of trends which have gained ground in recent years. The role of fiscal policy in eliminating or at least mitigating the consequences of the Covid-19 pandemic is also prominent, in contrast to monetary policy which is actually overburdened in many respects.

The scientific novelty of our study can be summarised in that we did not discuss the factors dynamising the current debt reduction in isolation, but using a debt decomposition procedure we made a comparison to an earlier period that in many ways was similar to the current one. A further area of research could be mapping, by country, the driving forces behind the results we produced. It may be particularly instructive to compare the fiscal performance of countries involved in international programmes (IMF, EU) to that of a control group of non-programme countries. It may also be of interest to analyse the contribution of fiscal policy to economic growth (structural reforms, growth-enhancing budget investments, etc.). 


\section{References}

Ábel, I. - Kóbor, Á. (2011): Növekedés, deficit és adósság - fenntartható keretben (Growth, deficit and debt - in a sustainable framework). Közgazdasági Szemle (Economic Review), 58(6): 511-528.

Agnello, L. - Sousa, R.M. (2009): The Determinants of Public Deficit Volatility. ECB Working Paper No. 1042. European Central Bank. https://www.ecb.europa.eu/pub/pdf/scpwps/ ecbwp1042.pdf

Aizenman, J. - Marion, N. (2009): Using Inflation to Erode the US Public Debt. NBER Working Paper 15562. http://doi.org/10.3386/w15562

Alesina, A. - Campante, F.R. - Tabellini, G. (2008): Why is Fiscal Policy Often Procyclical? Journal of the European Economic Association, 6(5): 1006-1036. https://doi.org/10.1162/ JEEA.2008.6.5.1006

Alesina, A. - Perotti, R. (1995): Fiscal Expansions and Fiscal Adjustments in OECD Countries. NBER Working Papers 5214. http://doi.org/10.3386/w5214

Alesina, A. - Perotti, R. (1997): Fiscal Adjustments in OECD countries: Composition and Macroeconomic Effects. NBER Working Papers 5730. http://doi.org/10.3386/w5730

Balatoni, A. (2015): A simple fiscal rule for Hungary. Acta Oeconomica, 65(1): 149-159. https://doi.org/10.1556/032.65.2015.s1.9

Baldacci, E. - Gupta, S. - Mulas-Granados, C. (2014): Debt Reduction, Fiscal Adjustment, and Growth in Credit-Constrained Economies. IMF Working Paper No. 13/238. International Monetary Fund. https://doi.org/10.5089/9781475516500.001

Bernanke, B. (2004): The Great Moderation. Remarks at the meeting of the Eastern Economic Association on February 20, 2004, Washington D.C. www.federalreserve.gov/boarddocs/ speeches/2004/20040220/default.htm

Bernardini, S. - Cottarelli, C. - Galli, G. - Valdes, C. (2019): Reducing public debt: the experience of advanced economies over the last 70 years. Policy Brief. https://doi. org/10.2139/ssrn.3405018

Bolle, M.B. de - Rother, B. - Hakobyan, I. (2006): The level and composition of public sector debt in emerging market crises. IMF Working Paper No. 6/186. International Monetary Fund. https://www.imf.org/external/pubs/ft/wp/2006/wp06186.pdf

Bouabdallah, O. - Checherita-Westphal, C.D. - Warmedinger, T. - De Stefani, R. - Drudi, F. - Setzer, R. - Westphal, A. (2017): Debt sustainability analysis for euro area sovereigns: a methodological framework. ECB Occasional Paper No. 185. https://www.ecb.europa. eu/pub/pdf/scpops/ecbop185.en.pdf 
Burnside, A.C. (ed.) (2005): Fiscal Sustainability in Theory and Practice: A Handbook. The World Bank Publications. Washington D.C. https://doi.org/10.1596/978-0-8213-5874-0

Castro, F. - De Cos, P.H. (2002): On the Sustainability of the Spanish Public Budget Performance. Revista de Economía Pública, 160(1): 9-27. https://core.ac.uk/download/ pdf/6836082.pdf

Cherif, R. - Hasanov, F. (2010): Public Debt Dynamics and Debt Feedback. MPRA Paper No. 27918. https://mpra.ub.uni-muenchen.de/27918/

Escolano, M.J. (2010): A practical guide to public debt dynamics, fiscal sustainability, and cyclical adjustment of budgetary aggregates. Technical Notes and Manuals, International Monetary Fund. https://doi.org/10.5089/9781462396955.005

European Commission (2010): European Economic Forecast - Spring 2010. European Economy, 2. https://ec.europa.eu/economy_finance/publications/european_ economy/2010/pdf/ee-2010-2_en.pdf

European Commission (2018): European Economic Forecast - Autumn 2018. Institutional paper 089. https://ec.europa.eu/info/sites/info/files/economy-finance/ip089_en_0.pdf

European Commission (2019): Fiscal Sustainability Report 2018. Institutional Paper 094. https://ec.europa.eu/info/sites/info/files/economy-finance/ip094_en_vol_1.pdf

Ghosh, A. - Kim, J. - Mendoza, E. - Ostry, J. - Qureshi, M. (2013): Fiscal fatigue, fiscal space and debt sustainability in advanced economies. The Economic Journal, 123(566): F4-F30. https://doi.org/10.1111/ecoj.12010

Grauwe, P. de - Ji, Y. (2019): Rethinking fiscal policy choices in the euro area. VOX, CEPR Policy Portal, 14 October. https://voxeu.org/article/rethinking-fiscal-policy-choices-euro-area

Győrffy, D. (2014): Válság és válságkezelés Görögországban: A puha költségvetési korlát szerepe a gazdasági összeomlásban (Crisis and crisis management in Greece. The role of soft budget constraints in the economic collapse). Közgazdasági Szemle (Economic Review), 61(1): 27-52.

Hall, G.J. - Sargent, T.J. (2010): Interest Rate Risk and Other Determinants of Post-WWII U.S. Government Debt/GDP Dynamics. NBER Working Paper No. 15702. http://doi. org/10.3386/w15702

Hasko, H. (2007): Some Unpleasant Fiscal Arithmetic: The Role of Monetary and Fiscal Policy in Public Debt Dynamics since the 1970s. Bank of Finland Research Discussion Paper 28. https://helda.helsinki.fi/bof/bitstream/handle/123456789/7847/156463. pdf;jsessionid=C501962D1591DA8F0DCCC07B4EA06F64? sequence $=1$ 
IMF (2020): The great lockdown. World Economic Outlook (Chapter 1). International Monetary Fund, Washington. https://www.imf.org/en/Publications/WEO/Issues/2020/04/14/weoapril-2020

La Torre, D. - Marsiglio, S. (2019). A note on optimal debt reduction policies. Macroeconomic Dynamics, 1-11. http://doi.org/10.1017/S1365100519000014

Lehmann, K. - Nagy, O. - Szalai, Z. - H. Váradi, B. (2020): Coordination(?) between the Branches of Economic Policy across the Euro Area. Financial and Economic Review, 19(1): 37-64. http://doi.org/10.33893/FER.19.1.3764

Losoncz, M. (2014): Az államadósság-válság és kezelése az EU-ban (The government debt crisis and its management in the EU). Tri-Mester, Tatabánya.

Mauro, P. - Zilinsky, J. (2016): Reducing government debt ratios in an era of low growth. Policy brief No. PB16-10. Peterson Institute for International Economics. https://www. piie.com/system/files/documents/pb16-10.pdf

Mellár, T. (2002): Néhány megjegyzés az adósságdinamikához (Some remarks on debt dynamics). Közgazdasági Szemle (Economic Review), 49(8): 725-740.

Muraközy, L. (2012): Államok kora. Az európai modell (The period of states. The European model). Akadémiai kiadó. Budapest.

Musgrave, R.A. (1959): The Theory of Public Finance. New York: McGraw-Hill.

Nagy, O. - Szalai, Z. - H. Váradi, B. (2020): A maastrichti kritériumok-feltételek és feltevések. (The Maastricht criteria - conditions and assumptions.) In: Virág, B. (ed.): Fenntartható felzárkózás euróval - Hogyan újítsuk meg a maastrichti kritériumokat? (Long-term sustainability and the euro - how to rethink the Maastricht criteria?). Magyar Nemzeti Bank, pp. 19-38.

P. Kiss, G. (1999): A fiskális politika jelzőszámai (Indicators of fiscal policy). Közgazdasági Szemle (Economic Review), 46(4): 307-325.

P. Kiss, G. (2012): Distinkció és kikényszeríthetőség - a fiskális szabályrendszer alfája és ómegája (Distinction and enforceability - the alpha and omega of the fiscal frameworks). Pázmány Law Working Papers, No. 39. http://plwp.eu/docs/wp/2012/2012-39-PKiss.pdf

Presbitero, A.F. (2011): Total public debt and economic growth in developing countries. MoFiR working paper No. 44. http://docs.dises.univpm.it/web/quaderni/pdfmofir/Mofir044.pdf

Ra, S. - Rhee, C.Y. (2005): Managing the Debt: An Assessment of Nepal's Public Debt Sustainability. Nepal Resident Mission Working Paper. No. 6. Asian Development Bank, Mandaluyong City. https://think-asia.org/bitstream/handle/11540/3284/wp6. pdf?sequence $=1$ 
Reinhart, C.M. (2012): The Return of Financial Repression. CEPR Discussion Paper No. DP8947. https://ssrn.com/abstract=2066320

Reinhart, C.M. - Rogoff, K. (2009): This Time is Different. Princeton University Press, Princeton and Oxford.

Tóth, Cs.G. (2010): Állami keresletélénkités és automatikus stabilizátorok (Boosting demand by the state and automatic stabilisers). Pénzügyi Szemle (Public Finance Quarterly), 55(1): 51-68.

Tóth, Cs.G. (2011): Adósságdinamika és fenntarthatóság (Debt dynamics and sustainability). Statisztikai Szemle (Statistical Review), 89(12): 1242-1268.

Tóth, Cs.G. (2014): The Forecasting Capacity of Indicators Measuring Budget Sustainability. Public Finance Quarterly, 56(4): 511-528.

Tóth, Cs.G. (2017): A nemzeti költségvetési szabályok elterjedése és hatása Európában (The spread of national fiscal rules and their effect in Europe). Közgazdasági Szemle (Economic Review), 64(11): 1119-1147. https://doi.org/10.18414/KSZ.2017.11.1119 